Article

\title{
Diversity and Conservation of Cave-Dwelling Bats in the Brunca Region of Costa Rica
}

\author{
Stanimira Deleva * (iD) and Gloriana Chaverri \\ Recinto de Golfito, Universidad de Costa Rica, 4000 Alamedas, Golfito 60701, Costa Rica; \\ gchaverri@upacificosur.org \\ * Correspondence: stanimira.deleva@ucr.ac.cr; Tel.: +359-883-490-378
}

Received: 10 April 2018; Accepted: 30 May 2018; Published: 2 June 2018

\begin{abstract}
The Brunca region in Costa Rica contains the largest number of caves in the country, yet the diversity and distribution of bat species within those caves is currently unknown. Without this information, it is not possible to assess changes in populations and assemblages that may indicate severe damages to these critical roosting habitats, and to take evidence-based conservation actions. We present the first study to describe the diversity of cave-dwelling bat species in the Brunca region of Costa Rica in a large number of caves. We collected data of bat species diversity by direct observation and capturing bats inside roosts. Bats were observed in 38 of the 44 surveyed caves, representing 20 species from 4 families, with colony sizes ranging from a few individuals to $>7500$. In addition, we collected information about the human activities carried out in and around the roosts to assess potential threats that these sites face. Data indicate that caves suffer mostly from unregulated tourist visitation and that one of the most visited caves is also the one with the most species-rich bat assemblages. Our study determined the most important and vulnerable bat roosts in the region and shows the need for urgent conservation actions to protect them.
\end{abstract}

Keywords: bats; Brunca region; caves; conservation; Costa Rica; diversity

\section{Introduction}

Caves are broadly defined as natural openings in solid rock [1], and as such, they serve as the "windows" in which we glance into the underground. Caves have been attracting people's interest from prehistoric times by serving as shelters, sacred places, or sources of artistic expression [2], but present a significant challenge for scientific research because they are largely hidden from view and hardly accessible for exploration. Most caves do not appear on topographic maps or satellite images and are neglected by mainstream scientists, making cave research a priority for only a small number of highly dedicated individuals [3]. Their unique features, the complete absence of light, almost constant temperature, and high air humidity make caves a suitable habitat for a large variety of highly specialized organisms such as cave crickets $[1,4]$, and some vertebrates including the blind salamander and angel fish $[1,5]$. These organisms are so well adapted to the specific conditions in caves that they would not survive in a surface habitat.

Caves are dependent on energy sources brought by several organisms that forage at the surface and which use caves as shelter, such as oilbirds, swiftlets, and bats $[1,2,6]$. Bats, in fact, are so tightly associated with caves and are often so abundant that they can significantly modify these ecosystems by altering their microclimatic conditions and providing significant amounts of guano, the essential food source and base of the food chain in most caves [2,7]. In turn, caves provide bats a refuge from predators and inclement weather, and a critical venue for social interactions [8-10]. Caves are so important for bats worldwide that the majority of species, including many that are vulnerable and rare, are either specialized cave-dwellers or use caves temporarily [11]. Also, the largest aggregations of 
bats are found in caves, with numbers reaching several millions of individuals [12-14], which makes them critical roosts for species that form such large colonies.

Costa Rica is a bat diversity hotspot with 114 species, most of which are well represented in the southwestern Brunca region $[15,16]$. The Brunca region has the largest karst region $\left(185 \mathrm{~km}^{2}\right)$ and the largest number of caves $(n=156)$ in the country [17]. While many of the species that inhabit the region are known to roost in caves in other parts of their range $[15,18,19]$, there is still no baseline information about the populations of cave-dwelling bats in this region. Cave-dwelling bats are extremely important for the local ecosystems, playing the role of pollinators, seed-dispersers, and pest-suppressors [20]. Cave-related tourism activities are also becoming popular in the Brunca region [17], which makes the caves potential sources of local income, but also endangers cave-dwelling bats, which are often vulnerable to disturbance. Other threats that bats are facing include habitat loss and direct killing at their roosts. To the best of our knowledge, there is no information on distribution and the ecology of cave-dwelling bats in this region, nor information about which roosts contain large colonies or rare species of bats that need to be considered a conservation priority [18], or even the types of threats these roosts are facing. This study is the first to assess the diversity and distribution of cave-dwelling bats species in a large number of the caves in the country. Our study provides valuable information about underground roosts of conservation importance.

Monitoring cave roosts is a highly accurate method for estimating colony size, species composition, and seasonal changes in the populations of cave-dwelling bats [21,22], and in the temperate zones, it is a widely distributed activity with well-established traditions [23-25]. The regular monitoring of bat roosts is of particular importance to assess population decline in vulnerable species and for the identification of potential threats (e.g., disturbance or dangerous diseases) [26,27]. Roost monitoring is, however, uncommon in Costa Rica, where most of the research on bat diversity and distribution is conducted around research stations and with the method of mist-netting [28-30], and most recently also with acoustic monitoring at feeding or commuting sites. Our efforts are aimed at establishing roosts of national monitoring priority, which will help us assess population trends and serve as a base for conservation activities in the future.

Cave-dwelling bats are facing threats worldwide such as habitat loss, pollution, disturbance, quarrying and mining, guano extraction, and vandalism [31-33]. Bats that roost in caves are particularly vulnerable to human activities due to their tendency to aggregate in large colonies in a single roost, as a single disturbance event could lead to the eradication of an entire colony [10]. In the Neotropics, cave-dwelling bats face additional threats due to direct killing, as local residents attempt to eradicate species that are considered pests, specifically vampire bats (Desmodus rotundus) [34]. These bats are chased by cattle farmers and killed inside the caves where they roost, leading to the decline of other species as well [35]. The efforts against vampire bats threaten all of the cave-roosting bats, as people aiming to kill vampire bats do not distinguish the different species and often destroy all bats in a single roost [36]. It is crucial to obtain information about the distribution of cave-dwelling bats in Costa Rica, so we can take conservation actions before important bat colonies are lost.

\section{Materials and Methods}

\subsection{Study Region}

We investigated caves and artificial tunnels in the Southwestern (Brunca) region of Costa Rica (N 9.23643, W 82.84233) at sites ranging in altitude from 0 to 520 masl. The Brunca region contains the largest karst area of the country, with $185 \mathrm{~km}^{2}$ of karst surface and 156 caves [17]. The region has an average annual temperature of $26.2^{\circ} \mathrm{C}$ and an average annual rainfall of $4398 \mathrm{~mm}$ [37]. The dominant habitat of the region is evergreen moist lowland forest, including large areas of well-preserved rainforests in the Corcovado and Amistad national parks [38]. For a better visual portrayal of the field sites, we roughly divided them into 5 areas (Figure 1): area A-Ballena, area B-Boruca, area C-Osa, area D—Rio Claro, and area E-Corredores. We do not provide the exact locations of the field sites to 
protect them from further disturbance; however, these data are available upon request from the digital repository Figshare (https: / figshare.com/projects/Diversity_and_conservation_of_cave-dwelling bats_in_the_Brunca_region_of_Costa_Rica/34415).

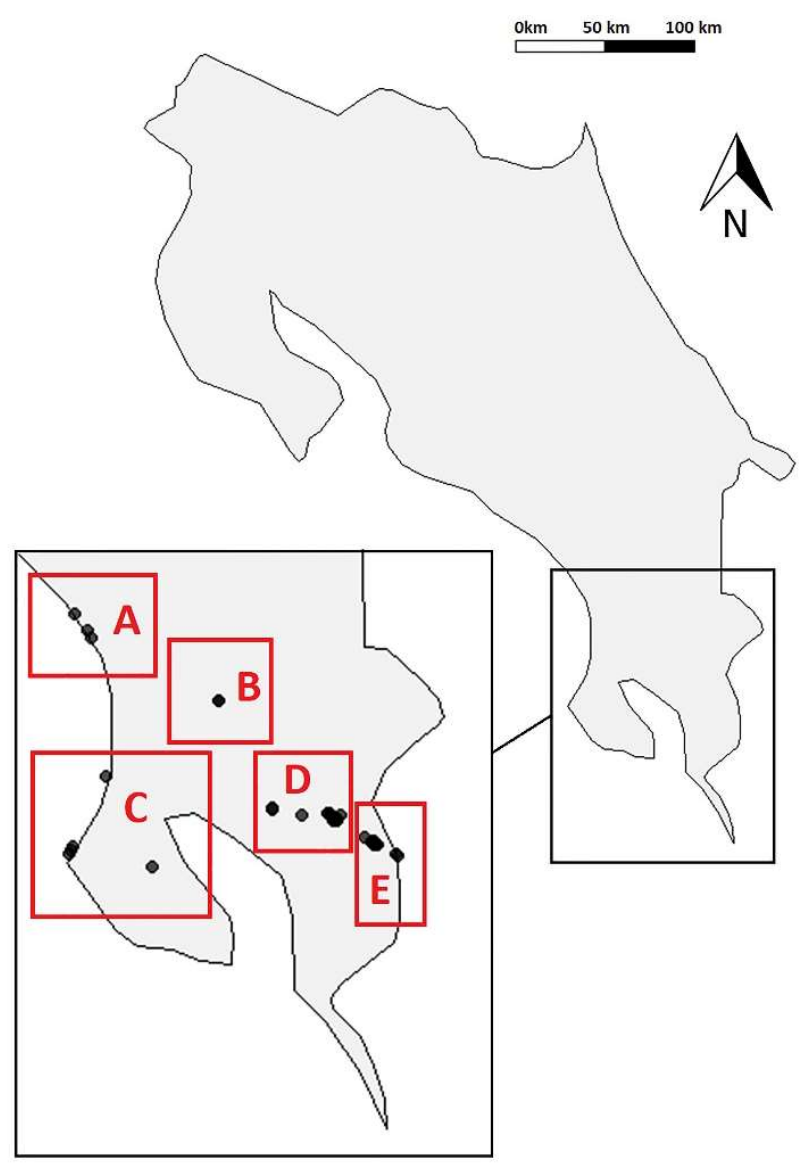

Figure 1. The Brunca region on the map of Costa Rica and the general location of the field work sites (marked by black dots), divided into 5 areas: (A) Ballena, (B) Boruca, (C) Osa, (D) Rio Claro, and (E) Corredores.

\subsection{Cave Surveys}

We obtained information about the existing caves in the Brunca region by consulting with the members of the only caving organization in Costa Rica-Anthros Speleological Group. The organization manages a national cave database, containing maps and descriptions of more than 340 caves in the country [39], which we used to select caves for research. Our selection of caves for this study was based on their size (in favor of greater length and depth) and available information about the presence of bat colonies in expedition reports [40]. We selected for research 14 caves from the national database and searched for additional caves by interviewing local people and performing transects in karst areas.

Our research took place during the periods from December 2015-May 2016, October 2016-May 2017, and December 2017-February 2018. We recorded the location and altitude of each cave using a GPS unit (Garmin, KS, USA). We entered the caves during daylight hours in groups ranging from two to four people using standard caving equipment (i.e., helmet, two independent light sources, and protective clothing). To survey the caves with vertical passages we used technical equipment and followed the approach of the single-rope technique [41]. We used the available cave maps to aid our movement inside the caves and to facilitate our bat surveys. If maps were not available, we created them using standard cave survey methods [42]. The number of visits varied between 1 and 4 times, depending on the complexity of the roost and the presence of bats during our first visit (Appendix A, 
Table A1, column D). If we observed only a few (<30) bats and low species richness ( 1 or 2 species), we visited the roost only once. When a large number of individuals or indirect traces of presence (e.g., guano, food remains) was observed during our first visit, we performed additional monitoring and tried to obtain data in both the rainy and dry seasons if possible. Due to high water levels and technical difficulties, some caves were inaccessible during the rainy season, so we visited them in the intermediate period between seasons (December-January and May-June).

In addition to the field surveys, we interviewed local people about the activities conducted in caves. We included questions about visitation, hunting, other uses of the caves, and awareness about bat populations. We focused on farmers and landowners living near the locations of the caves. We also used direct observations in and around roosts to assess additional anthropogenic activities. For example, we recorded evidence of graffiti, waste, broken speleothems, footprints, entrance blocking or traces of resource extraction inside the roosts. In proximity to the roosts (radius of $1 \mathrm{~km}$ ), we recorded the land use activities (agriculture, deforestation, quarrying). Depending on the dimension of the activities, we evaluated them on a scale from 1 to 4,1 being the highest and 4 the lowest disturbance.

\subsection{Bat Surveys}

We used flashlights and binoculars to search visually for roosting bats or indirect traces of their presence (i.e., skulls, guano or food remains) [43]. Small clusters of bats (up to 50 individuals) were counted directly at the cave. We photographed larger groups of bats using a digital DSLR camera (D3200, Nikon, Tokyo, Japan) and used ImageJ software [44] to estimate the number of individuals. We determined the species of observed bats using the available literature $[15,16,45]$ as a reference. To confirm species identification and obtain biometric data, we used a custom-made hand-held $2 \mathrm{~m}$ mist net to capture a few individuals within the roost. We measured forearm length, sex, age, and reproductive status of the captured bats [21]. In one vertical cave, we used a harp trap at the entrance to capture bats during their evening emerge. After taking biometric data, we released all individuals without further disturbance. No voucher specimens were collected during this study. We operated under the research permit INV-ACOSA-018-16.

\subsection{Assessing Conservation Priority}

We evaluated the conservation priority of each cave using the Bat Cave Vulnerability Index (BCVI), based on the bat species diversity and presence of human-induced threats in the caves [46]. The index is a novel approach for conservation prioritization of bat caves and it was developed with a focus on tropical regions. It contains two components: Biotic Potential Index (BP) and Biotic Vulnerability Index (BV). The Biotic Potential Index includes several species diversity and rarity measurements, including species richness, abundance, relative abundance, endemism, conservation status [47], and rarity index. The BP index has a value between 1 and 4 , with level 1 being the highest and 4 the lowest biotic potential. The Biotic Vulnerability Index includes information on cave accessibility, morphology, visitation, and land use in adjacent areas. The BV index has a value of $\mathrm{A}, \mathrm{B}, \mathrm{C}$, and $\mathrm{D}$, with $\mathrm{A}$ being the highest vulnerability to disturbance and $\mathrm{D}$ no disturbance. We classified all roosts based on the combined values of BP and BV. The roosts with indicated values of $1 \mathrm{~A}$ and $1 \mathrm{~B}$ were considered of highest conservation priority. The roosts with values between $1 \mathrm{C}$ and 3D were considered as medium conservation priority, and the roosts in category 4 of low priority.

\section{Results}

In the study period we visited 44 underground roosts, including 40 caves, 2 artificial tunnels, and 2 abandoned gold mines. From the researched caves, 30 were described for the first time during this study and included in the National Cave Database, and named after geographical or morphological features in their respective locations (Appendix A, Table A1). From all caves, 22 were horizontal and 22 were vertical (Appendix A, Figure A1). We observed bats in 38 of the 44 roosts. We identified 20 species of bats from the families Phyllostomidae, Emballonuridae, Natalidae and Mormoopidae 
(Table 1, Figure 2). The most frequently observed species was Carollia perspicillata, which occurred in 25 roosts. Other common species were Peropteryx kappleri (found in 18 roosts) and Saccopteryx bilineata (14 roosts). We observed relatively large $(n>100$ ind.) colonies of bats (Anoura sp., Artibeus jamaicensis, C. perspicillata, Desmodus rotundus, Natalus mexicanus, Pteronotus gymnonotus, Pteronotus parnellii, and Pteronotus personatus) in 11 caves and very large (>500 ind.) (C. perspicillata, P. gymnonotus, P. parnellii, and P. personatus) in 6 caves (Appendix A, Table A1). The largest colony of bats was observed in the Campanario cave, estimated at around 7600 individuals, and included three species of the genus Pteronotus (Appendix A, Table A1). Other large colonies are those found in the Laguna Perdida (ca. 2000 individuals) and Corredores (ca. 1500 individuals) caves. The roost with the greater species richness was Corredores, with 8 species, followed by Emus and Laguna Perdida with 7 species (Appendix A, Table A1). Three caves were inhabited by mixed colonies of Pteronotus spp.: Tortuga, Campanario, and Corredores; the first two are considered maternity colonies since we observed hundreds of pups. Both Tortuga and Campanario are very similar littoral caves, which have a single entrance, leading to a simple chamber, and are partially filled with sea water during high tides. In the Campanario cave, we observed a third species of Pteronotus, P. personatus, which is so far the only known location of the species during this study. A single bat species occurred in 14 caves, specifically the greater dog-like bat (Peropteryx kappleri) and Seba's short-tailed bat (C. perspicillata), observed in 6 roosts each.

Table 1. Observed species of bats and their respective locations.

\begin{tabular}{|c|c|c|}
\hline Family & Species & Roosts \\
\hline \multirow{10}{*}{ Phyllostomidae } & Artibeus jamaicensis & Arelis, Carma, Corredores, Gran Galería, Túnel ICE 2, San Pedrillo \\
\hline & Carollia perspicillata & $\begin{array}{l}\text { Afrodiziaco Pozo, Alma, Árbol Caido, Bananal, Bombasa, Buena } \\
\text { Cueva, Caballo Muerto, Cinco Millones, Corredores, Dos Brazos, } \\
\text { Emús, Final } 7 \text { Pozo, Gran Galería, Gran Madre, Túnel ICE 1, } \\
\text { Túnel ICE 2, San Josecito, Laguna Perdida, Los Sueños, } \\
\text { Miramar Pozo, San Pedrillo, Sapo Gordo Pozo, Titi Mono, Tortuga }\end{array}$ \\
\hline & Carollia sowelli & Miramar \\
\hline & Chrotopterus auritus & Corredores \\
\hline & Desmodus rotundus & $\begin{array}{l}\text { Alma, Bombasa, Buena Cueva, Cinco Millones, Emús, Gran Madre, } \\
\text { Túnel ICE 2, San Josecito, Laguna Perdida, Los Sueños, Miramar }\end{array}$ \\
\hline & Lonchophylla robusta & Bombasa, Laguna Perdida \\
\hline & Lonchorhina aurita & Gran Madre, Miramar \\
\hline & Phyllostomus discolor & Arelis \\
\hline & Phyllostomus hastatus & Laguna Perdida \\
\hline & Trachops cirrhosus & Bombasa, San Pedrillo \\
\hline Emballonuridae & Peropteryx kappleri & $\begin{array}{l}\text { Alma, Arbol Caido, Arelis, Bamboo Pozo, Banano Quemado, } \\
\text { Caballo Muerto, Castillo Real, Cinco Millones, Cueva } 1 \text { No Name, } \\
\text { Cueva Cerca Cor, Emús, Gran Galería, Gran Madre, La Troja, } \\
\text { Metros 12, Monteadores, Rectángulo, Serpiente Dormida }\end{array}$ \\
\hline \multirow{3}{*}{ Mormoopidae } & Pteronotus gymnonotus & Campanario, Corredores, Tortuga \\
\hline & Pteronotus parnellii & $\begin{array}{l}\text { Bombasa, Campanario, Corredores, Emus, Túnel ICE 2, } \\
\text { Laguna Perdida, Los Sueños, Tortuga }\end{array}$ \\
\hline & Pteronotus personatus & Campanario \\
\hline
\end{tabular}




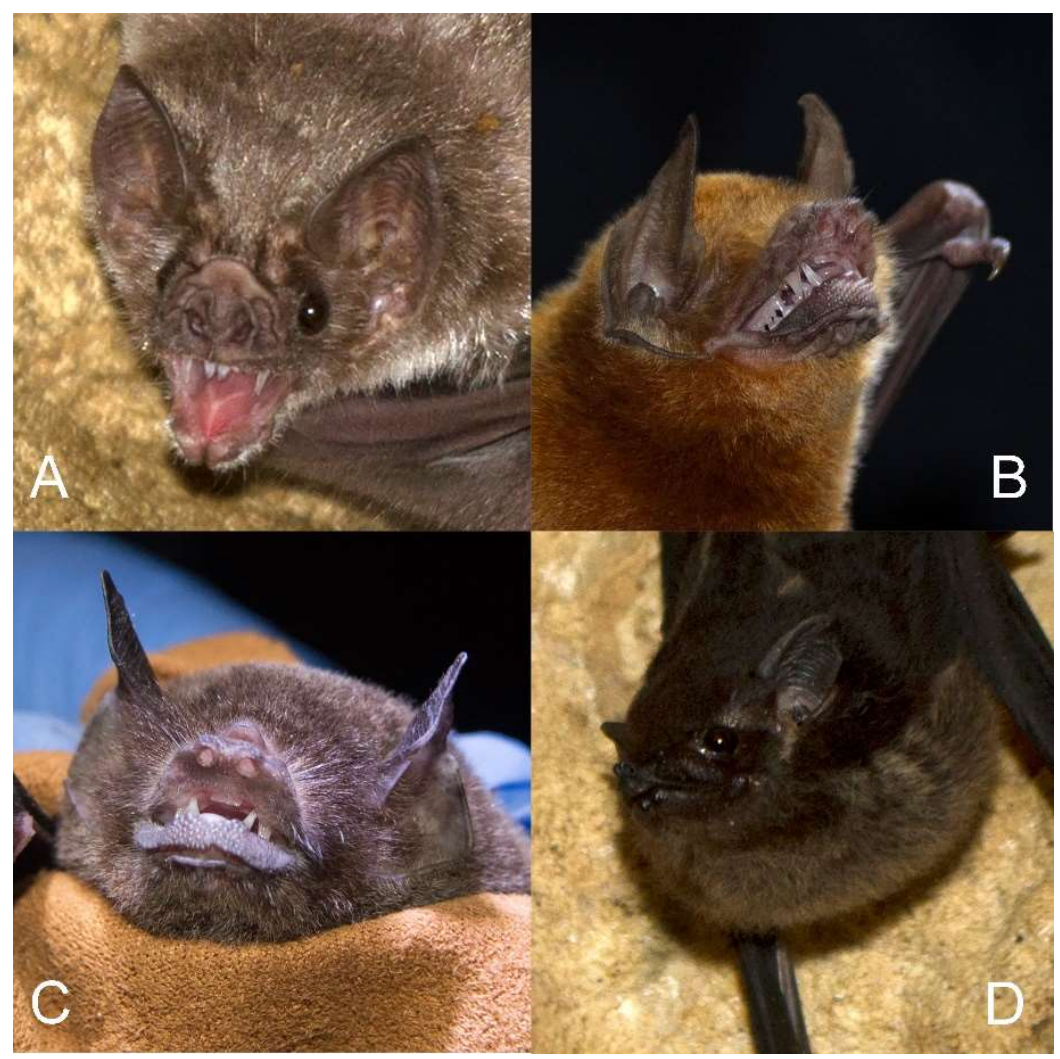

Figure 2. Some of the species, observed during our study: (A) Common vampire bat (D. rotundus), (B) Big naked-backed bat (P. gymnonotus), (C) Parnell's mustached bat (P. parnellii), and (D) Greater sac-winged bat (S. bilineata) (photos: S. Deleva).

We interviewed 10 groups of people, mainly farmers and landowners around the locations of the field sites. There were reports of hunting activities in two of the caves, in both of which we observed blocked entrances. Most of the farmers were not interested in the caves on their land and were not visiting them, but in two cases the owners were collecting entrance fees for their caves without offering other services, such as a guided tour or providing safety equipment. During our visits, six of the landowners showed us new caves and assisted in the explorations. From our observations inside the roosts, we recorded traces of uncontrolled visitation (footprints and waste) in 16 of the 44 roosts, vandalism (broken speleothems and graffiti) in two caves, and disposal of large quantities of household waste in one cave. The activities observed around the caves included small-scale agriculture and deforestation. Only three caves were located in a relatively undisturbed habitat (rainforest without agriculture activities in a $1 \mathrm{~km}$ radius around the cave entrance). We evaluated the morphological features of the roosts, difficulty of approach (distance to urbanized areas), cave use (tourism, hunting, littering, etc.), and the land-use activities around the roosts to calculate the Biotic Vulnerability Index (BV). According to the BV index, three caves had the highest level of vulnerability (Level A), and 13 caves showed high vulnerability (Level B). The rest of the caves $(n=27)$ had a lower level of vulnerability (Level C). Only one cave showed no disturbance (Level D) (Table 2).

Based on the Biotic Potential Index (BP), 11 caves had high diversity with large bat populations and high species richness, including rare species (Level 1). Only one cave was classified as Level 2 , with relatively large bat populations, and three caves were classified as level 3, with few species, mainly common, widespread, and small populations of bats. The other 29 caves were classified as level 4, as they showed very low species richness, represented by only a few individuals (Table 2).

We combined the two indexes to determine the roosts with the highest conservation priority (Bat Cave Vulnerability Index). Our results showed that nine caves have the highest conservation 
priority. The Tortuga cave received the highest $\mathrm{BCVI}(1 \mathrm{~A})$ due to the large bat colony and vulnerability. In addition, eight other caves (i.e., Arelis, Bombasa, Corredores, Dos Brazos, Emus, Túnel Ice 2, Laguna Perdida, and San Pedrillo) had a BCVI result of 1B-highest species diversity and very high vulnerability. Medium conservation priority caves were evaluated with BCVI values between $1 \mathrm{C}$ (High diversity and low vulnerability) and 3B (low diversity and high disturbance). The roosts with category $4 \mathrm{~A}, 4 \mathrm{~B}$, and $4 \mathrm{C}$ were evaluated as low conservation priority due to their low bat diversity (Table 2).

Table 2. Bat Cave Vulnerability Index (BCVI) as the combination of the Biotic Potential Index (BP) and the Biotic Vulnerability Index (BV), description of each observed category and the roosts.

\begin{tabular}{|c|c|c|c|c|}
\hline \multicolumn{2}{|c|}{ BCVI } & \multirow{2}{*}{ Priority } & \multirow{2}{*}{ Description * } & \multirow{2}{*}{ Roosts } \\
\hline BP & BV & & & \\
\hline 1 & A & High & $\begin{array}{l}\text { Large population, highest site accessibility, } \\
\text { highly prone to disturbance. }\end{array}$ & Tortuga \\
\hline 1 & B & High & $\begin{array}{l}\text { Large population, high species diversity, } \\
\text { high site accessibility, highly prone to } \\
\text { disturbance. }\end{array}$ & $\begin{array}{l}\text { Arelis, Bombasa, Corredores, Dos Brazos, Emus, } \\
\text { Túnel Ice 2, Laguna Perdida, San Pedrillo }\end{array}$ \\
\hline 1 & $\mathrm{C}$ & Medium & $\begin{array}{l}\text { Large population, high species diversity, } \\
\text { low site accessibility and less prone to } \\
\text { disturbance. }\end{array}$ & Campanario, Miramar \\
\hline 2 & $\mathrm{C}$ & Medium & $\begin{array}{l}\text { Relatively high population, low species } \\
\text { diversity, low site accessibility and less } \\
\text { prone to disturbance. }\end{array}$ & Carma \\
\hline 3 & B & Medium & $\begin{array}{l}\text { Small populations, relatively high species } \\
\text { diversity, high site accessibility, highly } \\
\text { prone to disturbance. }\end{array}$ & Alma, Gran Galeria \\
\hline 3 & $\mathrm{D}$ & Medium & $\begin{array}{l}\text { Relatively large population, low species } \\
\text { diversity, rare species present, low site } \\
\text { accessibility, not prone to disturbance. }\end{array}$ & Piedras Blancas 2 \\
\hline 4 & A & Low & $\begin{array}{l}\text { No bats present, highest site accessibility, } \\
\text { highly prone to disturbance. }\end{array}$ & Arco, Ventana \\
\hline 4 & B & Low & $\begin{array}{l}\text { Small populations, relatively high species } \\
\text { diversity, high site accessibility. }\end{array}$ & San Jocesito Cataratas, Los Sueños, Gran Madre \\
\hline 4 & $\mathrm{C}$ & Low & $\begin{array}{l}\text { Very small population, low species } \\
\text { diversity, lower site accessibility and less } \\
\text { prone to disturbance. }\end{array}$ & $\begin{array}{l}\text { Afrodiziaco, Aprendizaje, Arbol Caido, Bamboo, } \\
\text { Bananal, Banano Quemado, Buena Cueva, } \\
\text { Caballo Muerto, Castillo Real, Cinco millones, } \\
\text { Cueva 1, Cueva 3, Cueva 5, Cueva cerca } \\
\text { Corredores., Final 7, Túnel ICE 2, La Troja, } \\
\text { Lagrima, Metros 12, Monteadores, Rectangulo, } \\
\text { Sapo Gordo, Serpiente Dormida, Titi Mono. }\end{array}$ \\
\hline
\end{tabular}

\section{Discussion}

This study represents the first significant effort to characterize bat diversity in a large number of caves in Costa Rica. We provide new data on some additional roosting resources that are available to many bat species in the region, and our study will serve as a baseline for further research on the cave-dwelling bats in the Brunca region and in the country (Appendix A, Table A1). With our results, we have identified caves with a large number of species that potentially may require strong initiatives to protect, such as the Corredores and Laguna Perdida caves [46]. We have also identified colonies of a few species that are extremely rare and were only found in one or two caves, including Corredores and Emus (N. mexicanus in both, C. auritus in the former, and Peropteryx macrotis in the latter), Miramar (L. aurita), and Campanario (P. personatus), which points to the need for establishing strict visitation controls for all visitors (including speleologists) to secure the persistence of these colonies, as some of these species may be considered of high extinction risk [48]. These caves were not categorized as high-priority by the BCVI given that they do not suffer, yet, from human disturbance, as the caves are fairly inaccessible. Furthermore, we have also identified two maternity colonies that harbor large 
numbers of individuals from three species of the genus Pteronotus, primarily in the Campanario cave, but also in Tortuga (Figure 3). To secure the long-term persistence of these populations, visitation of these sites should never be allowed during lactation (February-May) as during this period, a single event of disturbance could lead to the detachment and fall (and possibly death) of hundreds of pups [25].

From the 44 studied caves, $38(86.36 \%)$ were occupied by bats, which represents a higher occupation rate than similar studies reported in other countries in Latin America. In Puerto Rico, for example, only 31\% of the caves in the National Speleology database are used as roosts [49]. A similar study in Brazil shows that only about half of the observed caves had bats [50]. We also found that in combination, all caves harbor a total of 20 species. However, we know that at least 46 species in the Brunca region of Costa Rica are considered cave-dwellers [15], and therefore, wonder why none of these other species were recorded in our study (Appendix A, Table A2). One possibility is that other roosting resources are more readily available to bats that are not cave-specialists, such as several species within the tribe Micronycterini (e.g., Micronycteris microtis and Lampronycteris brachyotis), which may often roost in hollow trees [51], and Artibeus lituratus, which is typically found roosting under foliage [52]. Alternatively, more vulnerable and rare species, such as the carnivorous bat Vampyrum spectrum and Macrophyllum macrophyllum [53-55], may have already disappeared from the area where the majority of study caves were located, as surrounding natural habitats face severe loss and/or significant degradation [38]. However, we hope that some of these other species will be recorded as we continue to monitor the same and additional cave roosts with a combination of other research techniques, including captures at the cave entrance and the use of ultrasound detectors [56].

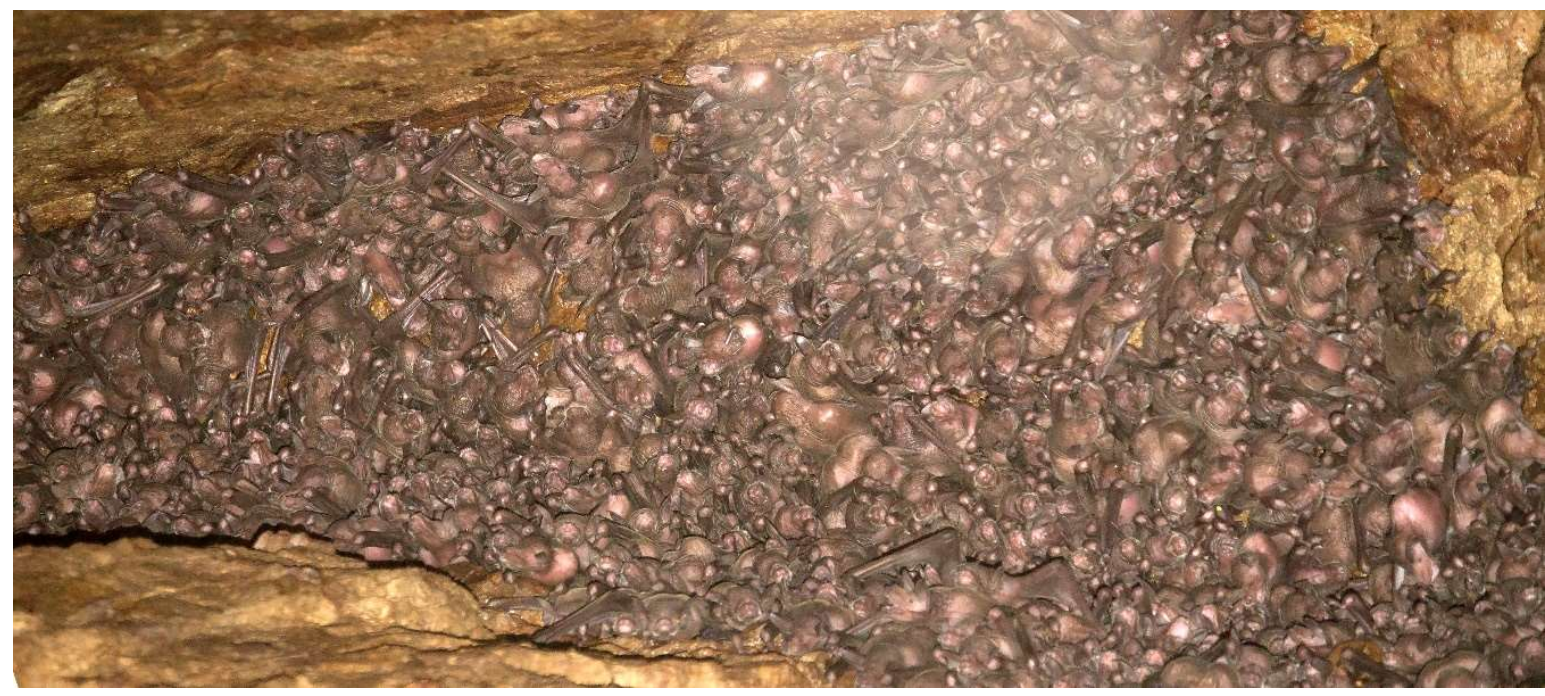

Figure 3. A nursery colony of Pteronotus spp. in the Tortuga cave (photo: S. Deleva).

From the 44 caves we visited, only two (i.e., Laguna Perdida and Piedras Blancas 2) are under some level of protection, as they are located in the Piedras Blancas National Park. There is no law protecting caves in Costa Rica, and most are located on private properties, which makes their protection a decision of the landowners. From the 114 species of bats in Costa Rica, at least 48 are cave-dwellers and depend on caves as roosts in one degree or another [15,57]. This makes the protection of caves and other underground roosts such as artificial tunnels and gold mines a matter of the highest priority. The most effective way to preserve the caves is to propose the roosts categorized as of high conservation priority as important sites for the conservation of bats (Sitio Importante para la Conservación de los Murciélagos), based on the documentation of the Latin American Bat Conservation Network [58]. Two of the caves with the highest conservation priority, Corredores and Emus, are also the most heavily affected by anthropogenic activities, such as uncontrolled visitation and vandalism, and both 
are readily accessible. Due to the frequent disturbance, the bat colonies in these caves are facing a dire future unless conservation groups, tour guides, and landowners join forces to set limits to visitation rates and enforce proper visitation guidelines [59].

The Bat Cave Vulnerability Index (BCVI) has further allowed us to identify roosts with high species diversity that are currently subject to anthropogenic pressure, thus urgent actions are needed to prevent further disturbance. Some roosts with high bat diversity are excluded from the list due to their difficult approach, which makes them less vulnerable to anthropogenic pressure. Others, which are highly vulnerable or already affected by anthropogenic activities, were excluded from the list due to low species diversity. We propose that if limited resources are available, we should focus our conservation efforts on the roosts of category $1 \mathrm{~A}$ and $1 \mathrm{~B}$, but the other categories need further monitoring, as new visits can detect new bat species or new threats that could be prevented before extensive damage is caused to the colonies [46].

\section{Conclusions}

With this study, we now have the tools to develop conservation strategies to protect the most important and vulnerable roosts and baseline information to start long-term monitoring programs of the bat colonies that inhabit these caves. Previous data of cave-dwelling bats in the Brunca region are available from a few expedition reports made in 1993, conducted mainly by non-specialists, that present general information about the presence of just a few bat species without information on their abundance [40]. As such, this report does not provide reliable baseline data to gauge changes in bat colony size and species assemblages that might allow us to determine if caves are suffering from human activities conducted in them, most notably uncontrolled visitation.

Our data confirm that caves in the Brunca region of Costa Rica are inhabited by a rich bat fauna and we must take urgent conservation efforts to protect them. Many of the bats in Costa Rica are of the lowest conservation priority (least concern) because of their wide distribution, but some species may be locally rare or declining. We propose cave surveys be included in the national priorities for bat research and an annual monitoring scheme for roosts to be set up. In this way, we will be able to trace the change in populations and to take actions if certain species are declining.

Author Contributions: Conceptualization, S.D. and G.C.; Methodology, S.D. and G.C.; Formal Analysis, S.D. and G.C.; Investigation, S.D. and G.C.; Resources, S.D. and G.C.; Data Curation, S.D.; Writing-Original Draft Preparation, S.D.; Writing-Review \& Editing, S.D. and G.C.; Visualization, S.D.; Supervision, G.C.; Funding Acquisition, S.D. and G.C.

Acknowledgments: This study was funded by a Rufford Small Grant (No 16923-1), the University of Costa Rica (Grant No B6033), and partially by the Alvaro Ugalde Grant of Osa Conservation. We also received a grant from Idea Wild. We thank Carlos Goicoechea and Gustavo Quesada for providing cave location data and the invaluable help for organizing field expeditions. We would like to express our gratitude to Angel Ivanov for his support during all stages of this research. We are also very grateful to all the cavers and researchers who provided an invaluable assistance in the field work: Cristian Castillo Salazar, Karen Miranda Gamboa, Scott Trescott, Richard Solano Quesada, Michael Martinez Bonilla, Inazio Garin, Jose Alfaro, Joxerra Aihartza, Leonard Baile, Amanda Vicente-Santos, Gustavo Alfaro Jimenez, Luis Ramirez Castro, Miranda Mitchell, Victor Hugo Carvajal Rivera, Félix Eduardo, Monica Lerici, Paula Iturralde-Polit, Wilson Hernández Cabrera, Esteban Zárate Brizuela.

Conflicts of Interest: The authors declare no conflict of interest. 


\section{Appendix A}

Table A1. All field sites in the Brunca region, their location (see Figure 1), visit dates, the Bat Cave Vulnerability Index (BCVI), and the Number of individuals of each species

\begin{tabular}{|c|c|c|c|c|c|c|c|c|c|c|c|c|c|c|c|c|c|c|c|c|c|c|c|c|}
\hline Cave & Area & Visits/mm/yy & BCVI & $\begin{array}{c}\text { Noof } \\
\text { Species }\end{array}$ & A sp. ** & $\underset{\text { jam }}{\mathrm{A}}$ & $\begin{array}{c}\text { C } \\
\text { per }\end{array}$ & $\begin{array}{c}\mathrm{C} \\
\text { sow }\end{array}$ & $\begin{array}{c}\mathrm{C} \\
\text { aur }\end{array}$ & $\begin{array}{c}\mathrm{D} \\
\text { rot }\end{array}$ & $\begin{array}{l}\text { G } \\
\text { sor }\end{array}$ & $\begin{array}{c}\mathrm{L} \\
\text { con }\end{array}$ & $\underset{\mathrm{rob}}{\mathrm{L}}$ & $\underset{\text { aur }}{\mathrm{L}}$ & $\begin{array}{c}\mathrm{N} \\
\text { mex }\end{array}$ & $\begin{array}{c}\text { rep } \\
\text { kap }\end{array}$ & $\underset{\mathrm{mac}}{\mathrm{P}}$ & $\begin{array}{c}\mathrm{P} \\
\text { dis }\end{array}$ & $\begin{array}{c}\mathrm{P} \\
\text { has }\end{array}$ & $\underset{\mathrm{gym}}{\mathrm{P}}$ & $\begin{array}{c}\mathrm{P} \\
\mathrm{par}\end{array}$ & $\begin{array}{c}P \\
\text { per }\end{array}$ & $\underset{\text { bil }}{s}$ & $\underset{\text { cir }}{\mathrm{T}}$ \\
\hline AFRODIZIACO POZO* & $\mathrm{D}$ & $03 / 16$ & $4 \mathrm{C}$ & 1 & 0 & 0 & 3 & 0 & 0 & 0 & 0 & 0 & 0 & 0 & 0 & 0 & 0 & 0 & 0 & 0 & 0 & 0 & 0 & 0 \\
\hline $\begin{array}{l}\text { APRENDIZAJE POZO * } \\
\text { APREA }\end{array}$ & $\begin{array}{l}\mathrm{E} \\
\mathrm{D}\end{array}$ & $03 / 16$ & $4 \mathrm{C}$ & $\begin{array}{l}5 \\
0\end{array}$ & 0 & ${ }_{0}^{0}$ & 0 & 0 & 0 & $\begin{array}{l}6 \\
0\end{array}$ & 0 & 0 & 0 & $\begin{array}{l}0 \\
0\end{array}$ & 0 & 0 & 0 & 0 & 0 & 0 & 0 & ${ }_{0}^{0}$ & $\begin{array}{c}13 \\
0\end{array}$ & ${ }_{0}^{0}$ \\
\hline ARBOL CAIDO * & $\mathrm{D}$ & $03 / 16$ & $4 \mathrm{C}$ & 2 & 0 & 0 & 14 & 0 & 0 & 0 & 0 & 0 & 0 & 0 & 0 & 11 & 0 & 0 & 0 & 0 & 0 & 0 & 0 & 0 \\
\hline $\mathrm{ARCO}^{*}$ & A & $02 / 16,05 / 16$ & $4 \mathrm{~A}$ & 0 & 0 & 0 & 0 & 0 & 0 & 0 & 0 & 0 & 0 & 0 & 0 & 0 & 0 & & 0 & 0 & 0 & 0 & 0 & 0 \\
\hline ARELIS * & D & $01 / 16 ; 04 / 16$ & $1 \mathrm{~B}$ & 4 & 0 & 22 & 0 & 0 & 0 & 0 & 0 & 0 & 0 & 0 & 0 & 45 & 0 & 36 & 0 & 0 & 0 & 0 & 55 & 0 \\
\hline $\begin{array}{l}\text { BAMBOO POZO * } \\
\text { BANANAL }\end{array}$ & ${ }_{\mathrm{F}}^{\mathrm{D}}$ & $\begin{array}{l}03 / 17 \\
01 / 17\end{array}$ & $\begin{array}{l}4 \mathrm{C} \\
4 \mathrm{C}\end{array}$ & ${ }_{1}^{2}$ & ${ }_{0}^{0}$ & $\begin{array}{l}0 \\
0 \\
0\end{array}$ & $\begin{array}{l}0 \\
9\end{array}$ & $\begin{array}{l}0 \\
0\end{array}$ & $\begin{array}{l}0 \\
0\end{array}$ & $\begin{array}{l}0 \\
0\end{array}$ & $0_{0}^{0}$ & $\begin{array}{l}0 \\
0\end{array}$ & $\begin{array}{l}0 \\
0\end{array}$ & 0 & 0 & ${ }_{0}^{12}$ & 0 & 0 & 0 & ${ }_{0}^{0}$ & 0 & 0 & 14 & 0 \\
\hline $\begin{array}{l}\text { BANANAL } \\
\text { BANANO QUEMADO }\end{array}$ & $\begin{array}{l}\mathrm{E} \\
\mathrm{E}\end{array}$ & $03 / 16$ & $\begin{array}{l}4 \mathrm{C} \\
4 \mathrm{C}\end{array}$ & $\begin{array}{l}1 \\
2\end{array}$ & ${ }_{0}^{0}$ & $\begin{array}{l}0 \\
0\end{array}$ & $\begin{array}{l}9 \\
0\end{array}$ & ${ }_{3}^{0}$ & $\begin{array}{l}0 \\
0\end{array}$ & $\begin{array}{l}0 \\
0\end{array}$ & ${ }_{0}^{0}$ & $\begin{array}{l}0 \\
0\end{array}$ & $\begin{array}{l}0 \\
0\end{array}$ & ${ }_{0}^{0}$ & $\begin{array}{l}0 \\
0\end{array}$ & 4 & $\begin{array}{l}0 \\
0\end{array}$ & $\begin{array}{l}0 \\
0\end{array}$ & $\begin{array}{l}0 \\
0\end{array}$ & $\begin{array}{l}0 \\
0\end{array}$ & $\begin{array}{l}0 \\
0\end{array}$ & ${ }_{0}^{0}$ & $\begin{array}{l}0 \\
0\end{array}$ & 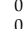 \\
\hline BOMBASA * & C & $02 / 18$ & $1 \mathrm{~B}$ & 6 & 0 & 0 & 350 & 0 & 0 & 1 & 40 & 0 & 20 & 0 & 0 & ${ }_{0}^{+}$ & & 0 & 0 & 0 & 100 & 0 & 0 & 1 \\
\hline IEVA * & D & $03 / 16$ & $4 \mathrm{C}$ & 2 & 0 & 0 & 74 & 0 & 0 & 2 & 0 & 0 & 0 & 0 & 0 & 0 & 0 & 0 & 0 & 0 & 0 & 0 & 0 & 0 \\
\hline CABALLO MUERTO * & D & $01 / 16,03 / 16$ & $4 \mathrm{C}$ & 2 & 0 & 0 & 3 & 0 & 0 & 0 & 0 & 0 & 0 & 0 & 0 & 4 & 0 & 0 & 0 & 0 & 0 & 0 & 0 & 0 \\
\hline CAMPANARIO * & ${ }_{\mathrm{E}}^{\mathrm{C}}-\mathrm{r}$ & $05 / 17,02 / 18$ & ${ }_{2 \mathrm{C}}^{1 \mathrm{C}}$ & 3 & ${ }_{0}^{0}$ & $\begin{array}{l}0 \\
179\end{array}$ & 0 & $\begin{array}{l}0 \\
0\end{array}$ & 0 & ${ }_{0}^{0}$ & 0 & 0 & 0 & ${ }_{0}^{0}$ & 0 & 0 & 0 & 0 & 0 & 2000 & 5000 & 600 & 0 & 0 \\
\hline $\begin{array}{l}\text { CARMA } \\
\text { CASTILLO REAL }\end{array}$ & $\underset{\mathrm{E}}{\mathrm{E}}$ & $\begin{array}{l}02216 \\
04 / 16\end{array}$ & $\begin{array}{l}2 \mathrm{C} \\
4 \mathrm{C}\end{array}$ & $\begin{array}{l}1 \\
1\end{array}$ & $\begin{array}{l}0 \\
0\end{array}$ & $\begin{array}{l}179 \\
0\end{array}$ & $\begin{array}{l}0 \\
0\end{array}$ & $\begin{array}{l}0 \\
0\end{array}$ & $\begin{array}{l}0 \\
0\end{array}$ & $\begin{array}{l}0 \\
0\end{array}$ & ${ }_{0}^{0}$ & $\begin{array}{l}0 \\
0\end{array}$ & $\begin{array}{l}0 \\
0\end{array}$ & $\begin{array}{l}0 \\
0\end{array}$ & $\begin{array}{l}0 \\
0\end{array}$ & $\begin{array}{l}0 \\
7\end{array}$ & $\begin{array}{l}0 \\
0\end{array}$ & $\begin{array}{l}0 \\
0\end{array}$ & $\begin{array}{l}0 \\
0\end{array}$ & $\begin{array}{l}0 \\
0\end{array}$ & $\begin{array}{l}0 \\
0\end{array}$ & $\begin{array}{l}0 \\
0\end{array}$ & ${ }_{0}^{0}$ & $0_{0}^{0}$ \\
\hline CINCO MIL & $\begin{array}{l}\mathrm{L} \\
\mathrm{D}\end{array}$ & 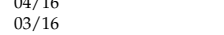 & $\begin{array}{l}4 \mathrm{C} \\
4 \mathrm{C}\end{array}$ & $\begin{array}{l}1 \\
4\end{array}$ & 0 & ${ }_{0}^{0}$ & 15 & 0 & 0 & 4 & 0 & 0 & 0 & 0 & 0 & 26 & 0 & 0 & 0 & ${ }_{0}^{0}$ & 0 & 0 & 20 & ${ }_{0}^{0}$ \\
\hline $\begin{array}{l}\text { CORREDORES } \\
\text { P }\end{array}$ & $\mathrm{E}$ & $01 / 16,03.16,02 / 16,12 / 17$ & $1 \mathrm{~B}$ & $\begin{array}{l}4 \\
8\end{array}$ & 0 & 14 & 49 & 0 & 1 & 0 & 1 & 0 & 0 & 0 & 235 & 0 & 0 & 0 & 0 & 500 & 700 & 0 & 8 & 0 \\
\hline CUEVA 1 & D & $01 / 16$ & $4 \mathrm{C}$ & 1 & 0 & 0 & 0 & 0 & 0 & 0 & 0 & 0 & 0 & 0 & 0 & 12 & 0 & 0 & 0 & 0 & 0 & 0 & 0 & 0 \\
\hline CUEVA 3 NO NAME * & D & $01 / 16$ & $4 \mathrm{C}$ & 0 & 0 & 0 & 0 & 0 & 0 & 0 & 0 & 0 & 0 & 0 & 0 & 0 & 0 & 0 & 0 & 0 & 0 & 0 & 0 & 0 \\
\hline $\begin{array}{l}\text { CUEVA } 5 \text { NO NAME * } \\
\text { CUEYA CERCA COR }\end{array}$ & $\mathrm{D}$ & $\begin{array}{l}01 / 16 \\
02 / 16\end{array}$ & ${ }_{4 \mathrm{C}}^{4 \mathrm{C}}$ & $\begin{array}{l}0 \\
1\end{array}$ & ${ }_{0}^{0}$ & $\begin{array}{l}0 \\
0\end{array}$ & $\begin{array}{l}0 \\
0\end{array}$ & ${ }_{0}^{0}$ & $\begin{array}{r}0 \\
0\end{array}$ & ${ }_{0}^{0}$ & ${ }_{0}^{0}$ & $\begin{array}{r}0 \\
0\end{array}$ & $\begin{array}{l}0 \\
0\end{array}$ & $\begin{array}{l}0 \\
0\end{array}$ & $\begin{array}{r}0 \\
0\end{array}$ & $\begin{array}{r}0 \\
22\end{array}$ & $\begin{array}{l}0 \\
0\end{array}$ & $\begin{array}{l}0 \\
0\end{array}$ & $\begin{array}{l}0 \\
0\end{array}$ & $\begin{array}{l}0 \\
0\end{array}$ & $\begin{array}{l}0 \\
0\end{array}$ & ${ }_{0}^{0}$ & ${ }_{0}^{0}$ & 0 \\
\hline DOS BRAZOS * & ${ }_{\mathrm{C}}^{\mathrm{E}}$ & $03 / 17,02 / 18$ & $1 \mathrm{~B}$ & $\begin{array}{l}1 \\
2\end{array}$ & 0 & $\begin{array}{l}0 \\
0\end{array}$ & 603 & ${ }_{0}^{0}$ & 0 & $\begin{array}{l}0 \\
0\end{array}$ & $\begin{array}{l}0 \\
90\end{array}$ & 0 & 0 & ${ }_{0}^{0}$ & 0 & ${ }_{0}^{22}$ & ${ }_{0}^{0}$ & ${ }_{0}^{0}$ & $\begin{array}{l}0 \\
0\end{array}$ & 0 & 0 & $a_{0}^{0}$ & ${ }_{0}^{0}$ & $\begin{array}{l}0 \\
0 \\
0\end{array}$ \\
\hline EMUS & $\mathrm{D}$ & $01 / 16,04 / 16,12 / 17$ & 1 & 7 & 0 & 0 & 813 & 0 & 0 & ${ }_{44}^{0}$ & 0 & 0 & 0 & 0 & 10 & 9 & 2 & 0 & 0 & 0 & 200 & 0 & 26 & 0 \\
\hline FINAL 7 POZO * & $\mathrm{D}$ & $03 / 16$ & $4 \mathrm{C}$ & 1 & 0 & 0 & 15 & 0 & 0 & 0 & 0 & 0 & 0 & 0 & 0 & 0 & 0 & 0 & 0 & 0 & 0 & 0 & 0 & 0 \\
\hline GRAN & E & $03 / 16,10 / 16,12 / 17$ & 3 в & 5 & 0 & 49 & 60 & 0 & 0 & 0 & 0 & 0 & 0 & 0 & 0 & 15 & 1 & 0 & 0 & 0 & 0 & 0 & 24 & 0 \\
\hline 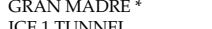 & $\begin{array}{l}\mathrm{D} \\
\mathrm{B}\end{array}$ & $\begin{array}{l}03 / 16,03 / 16 \\
0217\end{array}$ & $4 \mathrm{C}$ & 5 & ${ }_{0}^{0}$ & ${ }_{0}^{0}$ & 16 & 0 & 0 & ${ }^{4}$ & ${ }_{0}^{0}$ & 0 & 0 & 1 & 0 & 62 & 0 & ${ }_{0}^{0}$ & 0 & 0 & ${ }_{0}^{0}$ & 0 & 31 & 0 \\
\hline $\begin{array}{l}\text { IE } 1 \text { TUNNEL } \\
\text { ICE } 2 \text { TUNNNEL }\end{array}$ & $\begin{array}{l}\mathrm{B} \\
\mathrm{B}\end{array}$ & $02 / 17,12 / 17$ & $\begin{array}{l}4 \mathrm{C} \\
1 \mathrm{~B}\end{array}$ & $\begin{array}{l}1 \\
5\end{array}$ & $\begin{array}{l}0 \\
0 \\
0\end{array}$ & 320 & ${ }_{70}^{200}$ & ${ }_{0}^{0}$ & $\begin{array}{l}0 \\
0\end{array}$ & ${ }_{39}^{0}$ & ${ }_{0}^{0}$ & $\begin{array}{l}0 \\
0\end{array}$ & $\begin{array}{l}0 \\
0\end{array}$ & $\begin{array}{l}0 \\
0\end{array}$ & $\begin{array}{l}0 \\
0\end{array}$ & ${ }_{0}^{0}$ & ${ }_{0}^{0}$ & ${ }_{0}^{0}$ & $\begin{array}{l}0 \\
0\end{array}$ & ${ }_{0}^{0}$ & 150 & ${ }_{0}^{0}$ & ${ }_{12}^{0}$ & 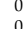 \\
\hline LA TROJA & $\mathrm{E}$ & $04 / 16$ & $\begin{array}{l}1 \mathrm{~B} \\
4 \mathrm{C}\end{array}$ & $\begin{array}{l}5 \\
1\end{array}$ & $\begin{array}{l}0 \\
0\end{array}$ & ${ }_{0}^{320}$ & 0 & 0 & 0 & 0 & 0 & 0 & 0 & 0 & 0 & 7 & 0 & 0 & 0 & 0 & 0 & $x_{0}$ & $\begin{array}{l}1 \\
0\end{array}$ & 0 \\
\hline LAGRIN & D & & $4 \mathrm{C}$ & 0 & 0 & 0 & 0 & 0 & 0 & 0 & 0 & 0 & 0 & 0 & 0 & 0 & 0 & 0 & 0 & 0 & 0 & 0 & 0 & 0 \\
\hline LAGUN & D & $10 / 16,10 / 16,12 / 17$ & $1 \mathrm{~B}$ & 7 & 100 & 0 & 1239 & 0 & 0 & 176 & 0 & 0 & 118 & 0 & 0 & 0 & 0 & 0 & 57 & 0 & 350 & 0 & 1 & 0 \\
\hline LOS SD & D & $11 / 16,02 / 18$ & $4 \mathrm{~B}$ & 4 & 0 & 0 & 250 & 0 & 0 & 25 & 0 & 0 & 0 & 0 & 0 & 0 & 0 & 0 & 0 & 0 & 4 & 0 & 65 & 0 \\
\hline $\begin{array}{l}\text { NAME* } \\
O *\end{array}$ & $\mathrm{D}$ & $15.01 / 6$ & ${ }^{4 \mathrm{C}}$ & $\frac{1}{5}$ & ${ }_{0}^{0}$ & ${ }_{0}^{0}$ & 00 & 0 & $\begin{array}{l}0 \\
0\end{array}$ & ${ }_{1}^{0}$ & ${ }_{0}^{0}$ & 0 & $\begin{array}{l}0 \\
0\end{array}$ & $\begin{array}{l}0 \\
108\end{array}$ & $\begin{array}{l}0 \\
0\end{array}$ & $\begin{array}{l}6 \\
0\end{array}$ & $\begin{array}{l}0 \\
0\end{array}$ & ${ }_{0}^{0}$ & $\begin{array}{l}0 \\
0 \\
0\end{array}$ & $\begin{array}{l}0 \\
0\end{array}$ & 0 & $\begin{array}{l}0 \\
0\end{array}$ & ${ }_{0}^{0}$ & 0 \\
\hline MONT & $\mathrm{E}$ & $01 / 16$ & $4 \mathrm{C}$ & $\begin{array}{l}5 \\
2\end{array}$ & 0 & ${ }_{0}^{0}$ & $\begin{array}{c}134 \\
0\end{array}$ & 0 & 0 & $\begin{array}{l}1 \\
0\end{array}$ & 0 & 0 & 0 & 0 & 0 & 8 & & $\begin{array}{l}0 \\
0\end{array}$ & $\begin{array}{l}0 \\
0\end{array}$ & 0 & ${ }_{0}^{0}$ & 0 & ${ }_{2}^{0}$ & 0 \\
\hline PIEDRAS BLANCAS 2* & $\mathrm{D}$ & $\begin{array}{l}10 / 17 \\
10 / 10\end{array}$ & $3 \mathrm{D}$ & 1 & 80 & 0 & 0 & 0 & 0 & 0 & 0 & 0 & 0 & 0 & 0 & 0 & 0 & 0 & 0 & 0 & 0 & 0 & 0 & 0 \\
\hline 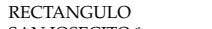 & $\mathrm{E}$ & & 4 & 2 & 0 & 0 & 0 & 0 & 0 & 0 & 0 & 0 & 0 & 0 & 0 & & & 0 & 0 & 0 & 0 & 0 & 4 & 0 \\
\hline ** & $\mathrm{C}$ & $05 / 17,02 / 18$ & 4 & 3 & 0 & 0 & 35 & 0 & 0 & 19 & 0 & 4 & 0 & 0 & 0 & 0 & 0 & 0 & 0 & 0 & 0 & 0 & 0 & 0 \\
\hline *zo* & C & & $1 \mathrm{~B}$ & 5 & 0 & 34 & 5 & ${ }_{0}^{0}$ & 0 & ${ }_{0}^{0}$ & ${ }_{0}^{0}$ & 50 & $\begin{array}{l}0 \\
0\end{array}$ & $0_{0}^{0}$ & 0 & 0 & ( & ${ }_{0}^{0}$ & 0 & 0 & 0 & ${ }_{0}^{0}$ & ${ }_{0}^{1}$ & 1 \\
\hline $\mathrm{DA}$ & E & 03 & $\begin{array}{l}4 \mathrm{C} \\
4 \mathrm{C}\end{array}$ & 1 & 0 & 0 & ${ }_{0}^{10}$ & 0 & 0 & 0 & 0 & 0 & 0 & 0 & 0 & 28 & 0 & 0 & 0 & 0 & 0 & 0 & 0 & 0 \\
\hline & D & & $4 \mathrm{C}$ & 1 & 0 & 0 & 4 & 0 & 0 & 0 & 0 & 0 & 0 & & 0 & & & 0 & 0 & & & 0 & 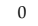 & 0 \\
\hline & A & 05 & $1 \mathrm{~A}$ & 3 & 0 & 0 & 6 & 0 & 0 & 0 & 0 & 0 & 0 & & 0 & & 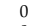 & 0 & & 7 & 400 & 0 & 0 & 0 \\
\hline ENTANA * & A & $05 / 16$ & $4 \mathrm{~A}$ & 0 & 0 & 0 & 0 & 0 & 0 & 0 & 0 & 0 & o & 0 & 0 & 0 & 0 & 0 & 0 & 0 & 0 & 0 & 0 & 0 \\
\hline
\end{tabular}

${ }^{*}$ New caves, according to the National Cave database. ${ }^{* *}$ Species abbreviations: Anoura sp., Artibeus jamaicensis, Carollia perspicillata, Carollia sowelli, Chrotopterus auritus, Desmodus rotundus, Glossophaga soricina, Lonchophylla concava, Lonchophylla robusta, Lonchorhina aurita, Natalus mexicanus, Peropteryx kappleri, Peropteryx macrotis, Phyllostomus discolor, Phyllostomus hastatus, Pteronotus gymnonotus, Pteronotus parnellii, Pteronotus personatus, Saccopteryx bilineata, Trachops cirrhosus. 
Table A2. Bat species in the Brunca region, their conservation status, population trend [51], presence in caves, and cave dependence [11,15,51].

\begin{tabular}{|c|c|c|c|c|c|}
\hline Common Name & Latin Name & IUCN Status & Population Trend & Cave-Dwelling & Cave-Dependent \\
\hline Handley's tailless bat & Anoura cultrata & LC & decreasing & Yes & No \\
\hline Geoffroy's tailless bat & Anoura geoffroyi & LC & stable & Yes & No \\
\hline Jamaican fruit bat & Artibeus jamaicensis & LC & stable & Yes & No \\
\hline Great fruit-eating bat & Artibeus lituratus & LC & stable & Yes & No \\
\hline Chestnut short-tailed bat & Carollia castanea & LC & stable & Yes & No \\
\hline Seba's short-tailed bat & Carollia perspicillata & LC & stable & Yes & No \\
\hline Sowell's short-tailed bat & Carollia sowelli & LC & stable & Yes & No \\
\hline Shaggy bat & Centronycteris centralis & LC & unknown & No & No \\
\hline Wrinkle-faced bat & Centurio senex & LC & stable & No & No \\
\hline Salvin's big-eyed bat & Chiroderma salvini & LC & stable & No data & No \\
\hline Hairy big-eyed bat & Chiroderma villosum & LC & stable & No & No \\
\hline Godman's long-tailed bat & Choeroniscus godmani & LC & unknown & No data & No data \\
\hline Big-eared wooly bat & Chrotopterus auritus & LC & stable & Yes & No \\
\hline Wagner's sac-winged bat & Cormura brevirostris & LC & unknown & No & No \\
\hline Aztec fruit-eating bat & Dermanura azteca & LC & unknown & Yes & No \\
\hline Toltec fruit-eating bat & Dermanura tolteca & LC & unknown & Yes & No \\
\hline Thomas' fruit eating bat & Dermanura watsoni & LC & stable & No & No \\
\hline Common vampire bat & Desmodus rotundus & LC & stable & Yes & No \\
\hline White-winged vampire bat & Diaemus youngi & LC & unknown & Yes & No \\
\hline Northern ghost bat & Diclidurus albus & LC & unknown & No & No \\
\hline Hairy-legged vampire bat & Diphylla ecaudata & LC & stable & Yes & No \\
\hline Velvety fruit-eating bat & Enchisthenes hartii & LC & unknown & No data & No data \\
\hline Brazilian brown bat & Eptesicus brasiliensis & LC & unknown & No & No \\
\hline Chirqui brown bat & Eptesicus chiriquinus & LC & unknown & No & No \\
\hline Argentine brown bat & Eptesicus furinalis & LC & unknown & Yes & No \\
\hline Big brown bat & Eptesicus fuscus & LC & increasing & Yes & No \\
\hline Black bonneted bat & Eumops auripendulus & LC & unknown & No & No \\
\hline Sanborn's bonneted bat & Eumops hansae & LC & unknown & No data & No data \\
\hline Commissaris's long-tongued bat & Glossophaga commissarisi & LC & stable & Yes & No \\
\hline Pallas's long-tongued bat & Glossophaga soricina & LC & stable & Yes & No \\
\hline Underwood's long-tongued bat & Hylonycteris underwoodi & LC & stable & Yes & Yes \\
\hline Yellow-throated big-eared bat & Lampronycteris brachyotis & LC & stable & Yes & No \\
\hline Desert red bat & Lasiurus blossevillii & LC & unknown & No & No \\
\hline Southern yellow bat & Lasiurus ega & LC & unknown & No & No \\
\hline Dark long-tongued bat & Lichonycteris obscura & LC & unknown & No data & No data \\
\hline Goldman's nectar bat & Lonchophylla concava & LC & unknown & Yes & No data \\
\hline Orange nectar bat & Lonchophylla robusta & LC & unknown & Yes & Yes \\
\hline Tomes's sword-nosed bat & Lonchorhina aurita & LC & stable & Yes & Yes \\
\hline Pygmy round-eared bat & Lophostoma brasiliense & LC & stable & No & No \\
\hline White-throated round-eared bat & Lophostoma silvicolum & LC & unknown & No & No \\
\hline Long-legged bat & Macrophyllum macrophyllum & LC & unknown & Yes & No data \\
\hline Hairy big-eared bat & Micronycteris hirsuta & LC & unknown & No & No \\
\hline
\end{tabular}


Table A2. Cont.

\begin{tabular}{|c|c|c|c|c|c|}
\hline Common Name & Latin Name & IUCN Status & Population Trend & Cave-Dwelling & Cave-Dependent \\
\hline Common big-eared bat & Micronycteris microtis & LC & stable & Yes & No \\
\hline White-bellied big-eared bat & Micronycteris minuta & LC & unknown & Yes & No \\
\hline Schmidts's big-eared bat & Micronycteris schmidtorum & LC & stable & No & No \\
\hline Striped hairy-nosed bat & Mimon crenulatum & LC & stable & No & No \\
\hline Coiban Mastiff Bat & Molossus coibensis & LC & unknown & No & No \\
\hline Velvety free-tailed bat & Molossus molossus & LC & unknown & No & No \\
\hline Miller's mastiff bat & Molossus pretiosus & LC & unknown & Yes & No data \\
\hline Black mastiff bat & Molossus rufus & LC & stable & No & No \\
\hline Sinaloan mastiff bat & Molossus sinaloae & LC & stable & Yes & No \\
\hline Silver-tipped myotis & Myotis albescens & LC & stable & Yes & No \\
\hline Hairy-legged myotis & Myotis keaysi & LC & unknown & Yes & No \\
\hline Black myotis & Myotis nigricans & LC & stable & Yes & No \\
\hline Montane myotis & Myotis oxyotus & LC & unknown & No data & No data \\
\hline Riparian myotis & Myotis riparius & LC & stable & No data & No data \\
\hline Mexican funnel-eared bat & Natalus mexicanus & LC & unknown & Yes & Yes \\
\hline Lesser bulldog bat & Noctilio albiventris & LC & stable & No & No \\
\hline Greater bulldog bat & Noctilio leporinus & LC & unknown & Yes & No \\
\hline Greater dog-like bat & Peropteryx kappleri & LC & unknown & Yes & No \\
\hline Lesser doglike bat & Peropteryx macrotis & LC & stable & Yes & No \\
\hline Pale spear-nosed bat & Phyllostomus discolor & LC & stable & Yes & No \\
\hline Greater spear-nosed bat & Phyllostomus hastatus & LC & stable & Yes & No \\
\hline Heller's broad-nosed bat & Platyrrhinus helleri & LC & stable & Yes & No \\
\hline Greater broad-nosed bat & Platyrrhinus vittatus & LC & unknown & Yes & No data \\
\hline Naked-backed bat & Pteronotus davyi & LC & stable & Yes & Yes \\
\hline Big naked-backed bat & Pteronotus gymnonotus & LC & stable & Yes & Yes \\
\hline Parnell's mustached bat & Pteronotus mesoamericanus & LC & unknown & Yes & Yes \\
\hline Wagner's mustached bat & Pteronotus personatus & LC & stable & Yes & Yes \\
\hline Thomas' yellow bat & Rhogeessa io & LC & unknown & No & No \\
\hline Proboscis bat & Rhynchonycteris naso & LC & unknown & No & No \\
\hline Greater sac-winged bat & Saccopteryx bilineata & LC & unknown & Yes & No \\
\hline Lesser sac-winged bat & Saccopteryx leptura & LC & unknown & No & No \\
\hline Talamancan yellow-shouldered bat & Sturnira mordax & NT & stable & No data & No data \\
\hline Mexican free-tailed bat & Tadarida brasiliensis & LC & stable & Yes & No \\
\hline Spix's disk-winged bat & Thyroptera tricolor & LC & unknown & No & No \\
\hline Stripe-headed round-eared bat & Tonatia saurophila & LC & stable & No & No \\
\hline Fringe-lipped bat & Trachops cirrhosus & LC & stable & Yes & No \\
\hline Niceforo's big-eared bat & Trinycteris nicefori & LC & unknown & No & No \\
\hline Tent-making bat & Uroderma bilobatum & LC & stable & No & No \\
\hline Striped yellow-eared bat & Vampyriscus nymphaea & LC & unknown & No & No \\
\hline Northern little yellow-eared bat & Vampyressa thyone & LC & unknown & No & No \\
\hline Great stripe-faced bat & Vampyrodes major & LC & unknown & No & No \\
\hline Spectral bat & Vampyrum spectrum & NT & decreasing & Yes & No \\
\hline
\end{tabular}



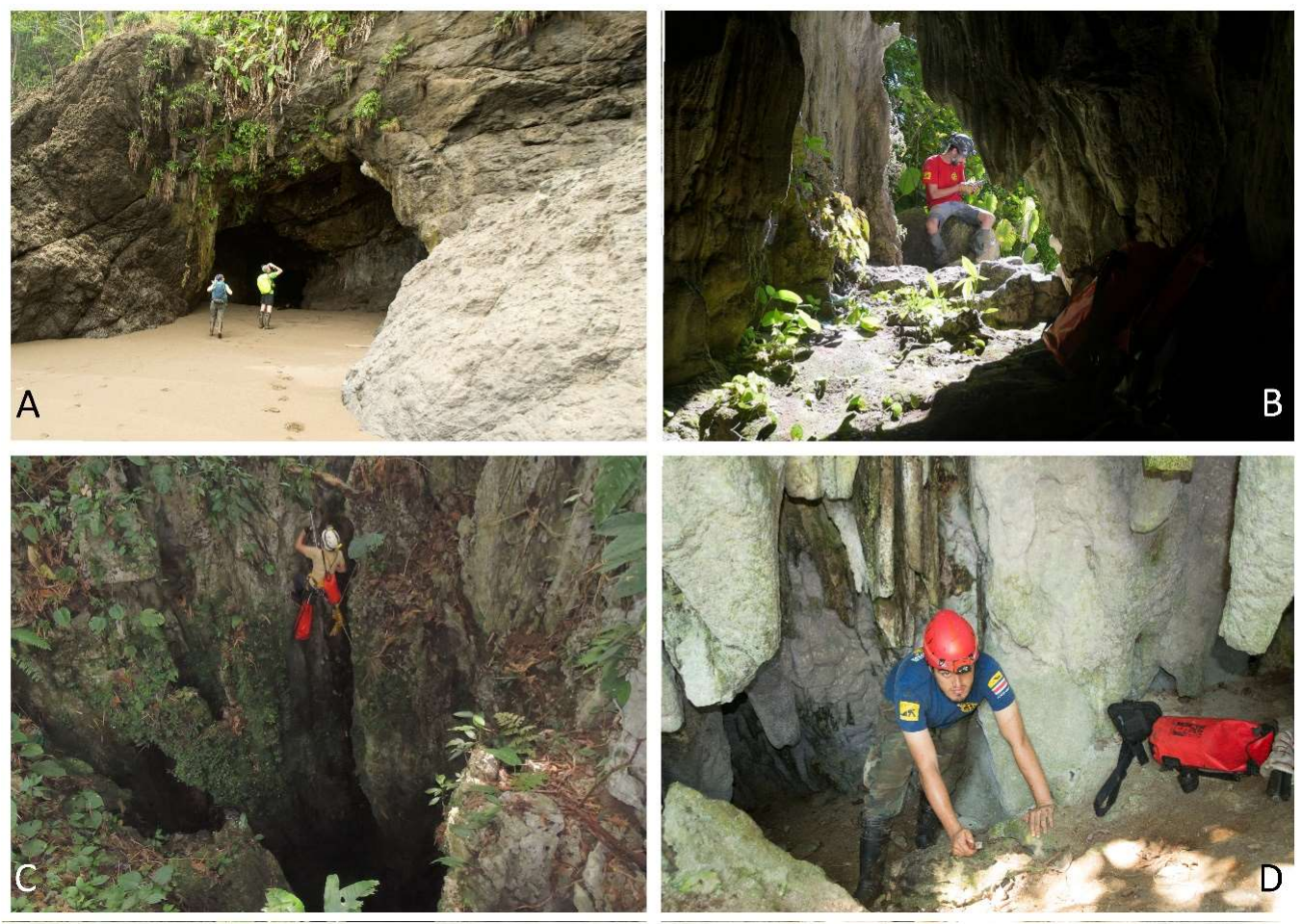

Figure A1. Some of the field work sites, mentioned in this study: (A) San Pedrillo cave, photo: S. Deleva; (B) Emus cave, photo: S. Trescott; (C) Bamboo cave, photo: C. Castillo Salazar; (D) Gran Madre cave, photo: S. Deleva.

\section{References}

1. Culver, D.; Pipan, T. The Biology of Caves and Other Subterranean Habitats; Oxford University Press: Oxford, UK, 2010.

2. Romero, A. Cave Biology; Cambridge University Press: Cambridge, UK, 2009.

3. Kambesis, P. The importance of cave exploration to scientific research. J. Cave Karst Stud. 2007, 69, 46-58.

4. Schilthuizen, M.; Cabanban, A.; Haase, M. Possible speciation with gene flow in tropical cave snails. J. Zool. Syst. Evol. Res. 2005, 43, 133-138. [CrossRef]

5. Vidthayanon, C. Cryptotora thamicola (Waterfall Climbing Cave Fish) the IUCN Red List of Threatened Species 2011. Available online: http:/ / www.iucnredlist.org/details /41407/0 (accessed on 15 March 2018).

6. Brinkløv, S.; Elemans, C.; Ratcliffe, J. Oilbirds produce echolocation signals beyond their best hearing range and adjust signal design to natural light conditions. R. Soc. Open Sci. 2017, 4, 170255. [CrossRef] [PubMed]

7. Ladle, R.; Firmino, J.; Malhado, A.; Rodríguez-Durán, A. Unexplored diversity and conservation potential of neotropical hot caves. Conserv. Biol. 2012, 26, 978-982. [CrossRef] [PubMed]

8. Ortega, J.; Maldonado, J. Female interactions in harem groups of the Jamaican fruit-eating bat, Artibeus jamaicensis (Chiroptera: Phyllostomidae). Acta Chiropterologica 2006, 8, 485-495. [CrossRef]

9. McCracken, G.; Gustin, M. Nursing behavior in Mexican free-tailed bat maternity colonies. Ethology 2010, 89, 305-321. [CrossRef]

10. Racey, P.; Furey, N. Conservation Ecology of cave bats. In Bats in the Anthropocene: Conservation of Bats in a Changing World; Voigt, C., Kingston, T., Eds.; Springer International Publishing: Berlin, Germany, 2016; pp. 463-500.

11. Sagot, M.; Chaverri, G. Effects of roost specialization on extinction risk in bats. Conserv. Biol. 2015, 29, 1666-1673. [CrossRef] [PubMed]

12. Sewall, B.; Granek, E.; Trewhella, W. The endemic Comoros islands fruit bat Rousettus obliviosus: Ecology, conservation, and red list status. Oryx 2003, 37. [CrossRef]

13. Hristov, N.; Betke, M.; Theriault, D.; Bagchi, A.; Kunz, T. Seasonal variation in colony size of brazilian free-tailed bats at Carlsbad cavern based on thermal imaging. J. Mammal. 2010, 91, 183-192. [CrossRef] 
14. McFarlane, D.; Rentergem, G.; Ruina, A.; Lundberg, J.; Christenson, K. Estimating colony size of the wrinkle-lipped bat, Chaerephon plicatus (Chiroptera: Molossidae) at Gomantong, Sabah, by quantitative image analysis. Acta Chiropterol. 2015, 17, 171-177. [CrossRef]

15. Reid, F. A Field Guide to the Mammals of Central America \& Southeast Mexico, 2nd ed.; Oxford University Press: Oxford, UK, 2009; pp. 72-176.

16. Trimm, R.; LaVal, R. A Field Key to the Bats of Costa Rica; Occasional Publication Series; Center for Latin American Studies; University of Kansas: Lawrence, KS, USA, 1999; Volume 22, pp. 1-20.

17. Ulloa, A.; Goicoechea, C. Geotourism Potential of Underground Sites in Costa Rica. Tour. Karst Areas 2013, 6, $43-56$.

18. Arita, H. Conservation Biology of the cave bats of Mexico. J. Mammal. 1993, 74, 693-702. [CrossRef]

19. Bats Living in Caves, Barra Honda National Park. Available online: http://docs.projects-abroad.org/ us / conservation-management-plan/data-and-reports/costa-rica/bats-living-in-caves.pdf (accessed on 15 March 2018).

20. Kunz, T.; Braun de Torrez, E.; Bauer, D.; Lobova, T.; Fleming, T. Ecosystem services provided by bats. Ann. N. Y. Acad. Sci. 2011, 1223, 1-38. [CrossRef] [PubMed]

21. Kunz, T.; Hodgkison, R.; Weise, S. Methods for capturing and handling bats. In Ecological and Behavioral Methods for the Study of Bats; Kunz, T., Parsons, S., Eds.; The Johns Hopkins University Press: Baltimore, MD, USA, 2009; pp. 5-35.

22. Flaquer, C.; Torre, I.; Arrizabalaga, A. Comparison of sampling methods for inventory of bat communities. J. Mammal. 2007, 88, 526-533. [CrossRef]

23. Atanasov, N. Novata peshtera cave near the town of Peshtera. Priroda Nauka 1936, 3, 75-77.

24. Petrov, B.; Helversen, O. Bats (Mammalia: Chiroptera) of the western Rhodopes Mountain (Bulgaria and Greece). In Biodiversity of Western Rhodopes (Bulgaria and Greece); Biodiversity of Bulgaria 4; Beron, P., Ed.; Pensoft \& National Museum of Natural History: Sofia, Bulgaria, 2011.

25. Battersby, J. Guidelines for Surveillance and Monitoring of European Bats; EUROBATS Publication Series No 5; UNEP/EUROBATS Secretariat: Bonn, Germany, 2010; Volume 5, p. 95.

26. Cardiff, S.; Ratrimomanarivo, F.; Rembert, G.; Goodman, S. Hunting, disturbance and roost persistence of bats in caves at Ankarana, northern Madagascar. Afr. J. Ecol. 2009, 47, 640-649. [CrossRef]

27. Foley, J.; Clifford, D.; Castle, K.; Cryan, P.; Ostfeld, R. Investigating and managing the rapid emergence of white-nose syndrome, a novel, fatal, infectious disease of hibernating bats. Conserv. Biol. 2011. [CrossRef] [PubMed]

28. Christenson, K.; Mcfarlane, D. An ecologically-significant range extension for Hahn's short-tailed fruit bat (Carollia Subrufa) in Southwestern Costa Rica. Chiropt. Neotrop. 2007, 13, 319-321.

29. Pacheco, J.; Ceballos, G.; Daily, G.; Ehrlich, P.; Suzán, G.; Rodríguez-Herrera, B.; Marcé, E. Diversidad, historia natural y conservación de los mamíferos de San Vito De Coto Brus, Costa Rica. Rev. Biol. Trop. 2014, 54, 219. [CrossRef]

30. Landmann, A.; Walder, C.; Vorauer, A.; Bohn, S.; Weinbeer, M. Bats of the La Gamba Region, Esquinas Rainforest, Costa Rica: Species diversity, guild structure and niche segregation. In Natural and Cultural History of the Golfo Dulce Region, Costa Rica; Einbeer, M., Ed.; Oberösterreichisches Landesmuseum, Biologiezentrum: Linz, Austria, 2008; pp. 423-440.

31. Hutson, A.M.; Mickleburgh, S.P. Racey, P.A. Michrochiropteran Bats: Global Status Survey and Conservation Action Plan; IUCN/SSC Chiroptera Specialist Group; IUCN: Gland, Switzerland; Cambridge, UK, 2001.

32. Baker, A.; Genty, D. Environmental pressures on conserving cave speleothems: Effects of changing surface land use and increased cave tourism. J. Environ. Manag. 1998, 53, 165-175. [CrossRef]

33. Medellin, R.; Wiederholt, R.; Lopez-Hoffman, L. Conservation relevance of bat caves for biodiversity and ecosystem services. Biol. Conserv. 2017, 211, 45-50. [CrossRef]

34. Kobayashi, Y.; Sato, G.; Mochizuki, N.; Hirano, S.; Itou, T.; Carvalho, A.; Albas, A.; Santos, H.; Ito, F.; Sakai, T. Molecular and geographic analyses of vampire bat-transmitted cattle rabies in central Brazil. BMC Vet. Res. 2008, 4, 44. [CrossRef] [PubMed]

35. Tuttle, M.; Moreno, A. Cave-Dwelling Bats of Northern Mexico: Their Value and Conservation Needs; Bat Conservation International: Austin, TX, USA, 2005.

36. BATS Magazine Article: Conserving Costa Rica's Bats. Available online: http://www.batcon.org/resources/ media-education/bats-magazine/bat_article/57 (accessed on 15 March 2018). 
37. Climate Ciudad Neily: Temperature, Climograph, Climate Table for Ciudad Neily-Climate-Data.org. Available online: https:/ / en.climate-data.org/location/1005481/ (accessed on 14 February 2018).

38. Gilbert, L.; Christen, C.; Altrichter, M.; Longino, J.; Sherman, P.; Plowes, R.; Swartz, M.; Winemiller, K.; Weghorst, J.; Vega, A.; et al. The Southern Pacific lowland evergreen moist forest of the Osa Region. In Costa Rican Ecosystems; Kappelle, M., Ed.; University of Chicago Press: Chicago, IL, USA, 2016; pp. 360-411.

39. Registro Kárstico Nacional (RKN) | Grupo Espeleológico Anthros. Available online: http: / /anthros.org/es / anthros/registro-karstico-nacional/ (accessed on 15 February 2018).

40. Peacock, N.; Hempel, J. Studies of the Rio Corredor Basin Bulletin 2-NSS Costa Rica Project; National Speleological Society Bulletin: Washington, DC, USA, 1993; Volume 55.

41. Marbach, G.; Tourte, B. Alpine Caving Techniques; Speleo Projects: Allschwil, Switzerland, 2002.

42. Paperless Cave Surveying. Available online: https://paperless.bheeb.ch/ (accessed on 15 February 2018).

43. Hayes, J.; Ober, H.; Sherwin, E. Surveying and monitoring bats. In Ecological and Behavioral Methods for the Study of Bats, 2nd ed.; Kunz, T., Parsons, S., Eds.; Johns Hopkins University Press: Baltimore, MD, USA, 2009; pp. 115-132.

44. Ferreira, T.; Rasband, W. Imagej. 2012. Available online: http://imagej.nih.gov/ij/docs/guide (accessed on 7 April 2018).

45. La Val, R.; Rodriguez-Herrera, B.; Tschapka, M.; Quesada, F.; Suárez, C.A.; Sistachs, O. Costa Rica Bats, 1st ed.; Editorial Inbio: San Jose, CA, USA, 2002.

46. Tanalgo, K.; Tabora, J.; Hughes, A. Bat Cave Vulnerability Index (BCVI): A Holistic Rapid Assessment Tool to Identify Priorities for Effective Cave Conservation in the Tropics. Ecol. Indic. 2018, 89, 852-860. [CrossRef]

47. The IUCN Red List of Threatened Species. Version 2017-3. Available online: http:/ / www.iucnredlist.org/ search?page $=1$ (accessed on 7 April 2018).

48. Rodriguez-Herrera, B.; Chinchilla, F.; May-Collado, L. Lista de especies, endemismo y conservación de los mamíferos de Costa Rica. Rev. Mex. Mastozool. 2002, 16, 21-57.

49. Rodriguez-Duran, A. Nonrandom aggregations and distribution of cave-dwelling bats in Puerto Rico. J. Mammal. 1998, 79, 141-146. [CrossRef]

50. Torquetti, C.; Silva, M.; Talamoni, S. Differences between caves with and without bats in a Brazilian karst habitat. Zoologia 2017, 34, 1-7. [CrossRef]

51. Medellin, R.; Wilson, D.; Daniel, L. Micronycteris brachyotis. Mamm. Species 1985, 1. [CrossRef]

52. Muñoz-Romo, M.; Herrera, E.; Kunz, T. Roosting behavior and group stability of the big fruit-eating bat Artibeus lituratus (Chiroptera: Phyllostomidae). Mamm. Biol. Z. Säugetierkunde 2008, 73, 214-221. [CrossRef]

53. Dinets, V. Long-term cave roosting in the spectral bat (Vampyrum Spectrum). Mammalia 2017, 81. [CrossRef]

54. Aguirre, L.; Mantilla, H.; Miller, B.; Dávalos, L. "Vampyrum Spectrum”. The IUCN Red List of Threatened Species 2008. Available online: http://dx.doi.org/10.2305/IUCN.UK.2008.RLTS.T22843A9395576.en (accessed on 7 April 2018).

55. Pineda, W.; Rodriguez, B. Macrophyllum macrophyllum: Rodriguez, IUCN Red List of Threatened Species 2015. Available online: http:/ / dx.doi.org/10.2305/IUCN.UK.2015-4.RLTS.T12615A22025883.en (accessed on 7 April 2018).

56. Rodríguez-Herrera, B.; Sánchez, R.; Pineda, W. First Record of Natalus lanatus (Chiroptera: Natalidae) in Costa Rica, and Current Distribution of Natalus in the Country. Ecotropica 2011, 17, 113-117.

57. Rodríguez-Herrera, B.; Ramírez-Fernández, J.; Villalobos-Chaves, D.; Sánchez, R. Actualización De La Lista De Especies De Mamíferos Vivientes De Costa Rica. Mastozool. Neotrop. 2014, 21, 275-289.

58. Áreas Importantes Para LA Conservación De Los Murciélagos (AICOMs) AICOMs y SICOMs-RELCOM-Red Latinoamericana y del Caribe Para la Conservación de Los Murciélagos. Available online: http:/ /www. relcomlatinoamerica.net/index.php/que-hacemos/conservacion/18-relcom/33-aicomsysicoms (accessed on 7 April 2018).

59. Sheffield, S.; Shaw, J.; Heidt, G.; McQenaghan, L. Guidelines for the protection of bat roosts. J. Mammal. 1992, 73, 707-710. [CrossRef]

(C) 2018 by the authors. Licensee MDPI, Basel, Switzerland. This article is an open access article distributed under the terms and conditions of the Creative Commons Attribution (CC BY) license (http:/ / creativecommons.org/licenses/by/4.0/). 